\title{
Effects of olive cake meal on serum constituents and fatty acid levels in breast muscle of Japanese quail
}

\author{
C. Ozcan ${ }^{1,}$ T. Cimrin ${ }^{\# 2}$, Y. Yakar ${ }^{3}$ \& S. Alasahan ${ }^{4}$ \\ ${ }^{1}$ Department of Animal Nutrition and Nutritional Diseases, Faculty of Veterinary Medicine, Siirt University, Siirt, Turkey \\ ${ }^{2}$ Department of Animal Science, Faculty of Agriculture, Hatay Mustafa Kemal University, Hatay, Turkey \\ ${ }^{3}$ Department of Food Engineering, Faculty of Engineering, Harran University, Şanlıurfa, Turkey \\ ${ }^{4}$ Department of Animal Breeding, Faculty of Veterinary Medicine, Hatay Mustafa Kemal University, Hatay, Turkey
}

(Received 20 July 2020; Accepted 28 October 2020; Published 23 December 2020)
Copyright resides with the authors in terms of the Creative Commons Attribution 4.0 South African License.
See: http://creativecommons.org/licenses/by/4.0/za
Condition of use: The user may copy, distribute, transmit and adapt the work, but must recognize the authors and the South African Journal of Animal Science.

\begin{abstract}
This study was aimed at determining the effects of various levels of dietary olive cake meal (OCM) on certain blood parameters and breast muscle fatty acid and cholesterol levels. For this purpose, 400 day-old Japanese quail (Coturnix coturnix japonica) chicks of both sexes were randomly assigned to four trial groups, each including five replicates of 20 animals. The quail were fed on a maize and soybean meal-based basal diet supplemented with $0 \%, 2.5 \%, 5 \%$ and $7.5 \%$ of OCM for six weeks. Dietary supplementation with $5 \%$ and $7.5 \%$ of OCM decreased total cholesterol and low-density lipoprotein cholesterol levels in the blood serum, and increased cholesterol levels in the breast muscle. Dietary supplementation with various levels of OCM decreased saturated fatty acid and polyunsaturated fatty acid levels, and increased monounsaturated fatty acid and total unsaturated fatty acid levels in the breast muscle. As a result, it was concluded that, olive cake meal, which contains a high level of olive oil, could be incorporated in poultry feed at a level of $5 \%$, owing to its beneficial effects of decreasing serum LDL cholesterol, which plays a major role in the aetiology of cardiovascular diseases, and in reducing saturated fatty acid levels in breast muscle.
\end{abstract}

Keywords: Coturnix coturnix japonica, feedstuff, monounsaturated fatty acids, oleic acid, olive by-product, stearic acid

\#Corresponding author: tcimrin@hotmail.com

\section{Introduction}

The investigation of optimized agricultural by-products has an important place in efforts to reduce feed costs and identify alternative feed sources. One by-product that offers potential is OCM, which is obtained by processing the pit, skin and pulp of olives after the oil has been extracted. Olive cake meal is made up of vitamin $\mathrm{E}$, calcium, iron, potassium, magnesium, sodium, phosphorus, $8-8.5 \%$ crude protein, and $8-10 \%$ olive oil (Anonymous, 2020). Owing to the share of oleic acid in its fatty acid content, olive oil contains a high level of monounsaturated fatty acids (MUFAs) (Chiofalo et al., 2002). By decreasing the generation of reactive oxygen species, oleic acid reduces fatty acid oxidation (Gonçalves-de-Albuquerque et al., 2016), and the risk of developing cardiovascular disease and cancer (Perdomo et al., 2015; Medeiros-de-Moraes et al., 2018). Thus, olive by-products offer more than merely being alternative feedstuffs (Stark et al., 2002). Reports indicated that feeding olive by-products increased serum total protein, albumin, high-density lipoprotein (HDL) cholesterol levels, and an increased HDL/LDL ratio associated with decreased total cholesterol and low-density lipoprotein (LDL) cholesterol levels, and reduced egg yolk cholesterol content (Al-Harthi, 2016; Saleh et al., 2020; Cayan \& Erener, 2015). Dietary supplementation with olive by-products has also been reported to improve serum lipid levels and increase the level of unsaturated fatty acids in the breast and thigh muscles, and thereby to increase the quality of animal products (Krejčí-Treu et al., 2010; Zhang et al., 2013; Tüzün \& Ünlü, 2016). Thus, this study was designed to investigate the effects of various levels of OCM on certain serum constituents and the fatty acid composition breast muscle. 


\section{Materials and Methods}

This study was approved by the Scientific Academic Research and Publication Ethics Board of Siirt University, dated 27 March 2019, and numbered 2019/01. The quail chicks used in this study were obtained by placing fertilized Japanese quail eggs from the Wildlife Conservation and Rehabilitation Research and Training Centre of Siirt University into incubators at the same centre for hatching.

In this study, 400 day-old Japanese quail chicks (Coturnix coturnix japonica) of both sexes were randomly assigned to four treatment groups, each with five replicates of 20 birds. The treatment groups were fed on a commercial grower feed (basal diet) $(20.69 \%$ crude protein and $2914.8 \mathrm{Kcal}$ ME per $\mathrm{kg}$ diet), supplemented with OCM. The diets were formulated to be isocaloric and isonitrogenous according to nutritional values published by the NRC (1994). The treatments were a basal control diet containing no OCM (C), and the same basal diet augmented with 2.5\% (T2.5), 5.0\% (T5), and 7.5\% (T7.5) OCM.

At the end of six weeks, the animals were weighed and the mean bodyweight was calculated for each group. From each group, ten males and ten females with bodyweights closest to the mean bodyweight of the group were slaughtered by cervical dislocation and blood samples were collected. Samples of breast muscle were obtained from five males and five females from each group and stored at $-20{ }^{\circ} \mathrm{C}$ until the fatty acid and cholesterol analyses were conducted.

Fat was extracted from the breast muscle samples (Folch et al., 1957) and methylated (ISO 12966:22017) (International Organization for Standardization, Geneva, Switzerland). The analyses were performed with a Thermo Scientific Trace GC model gas chromatograph (Thermo Fisher, Waltham, MO, USA) equipped with a flame ion detector (FID). An Agilent DB-WAX column ( $30 \mathrm{~m}, 0.32 \mathrm{~mm}, 0.25 \mu \mathrm{m})$ was used to detect fatty acids. The fatty acid standard (mixture of 37 fatty acids) was supplied by Sigma-Aldrich (St Louis, MO, USA). The temperatures of the detector and injector block were set to $280^{\circ} \mathrm{C}$ and $260^{\circ} \mathrm{C}$, respectively. A heating programme was applied in the column. After two minutes at $90^{\circ} \mathrm{C}$, the temperature was raised by $10{ }^{\circ} \mathrm{C}$ per minute to $200{ }^{\circ} \mathrm{C}$ and then $3{ }^{\circ} \mathrm{C}$ per minute to $230{ }^{\circ} \mathrm{C}$, and maintained at this final level for 12 minutes. The split rate was $1 / 50$ and the injection volume was $1 \mu \mathrm{L}$ (Anonymous, 1996).

The cholesterol content of the samples was measured (De Almeida et al., 2006) with an FID-equipped Thermo Scientific Trace GC model gas chromatograph and an Aglient HP-ULTRA 2 column (25 m, 0.32 $\mathrm{mm}, 0.17 \mu \mathrm{m})$. The temperatures of the detector, injection block and column were set to $290^{\circ} \mathrm{C}, 280^{\circ} \mathrm{C}$, and $260^{\circ} \mathrm{C}$, respectively. The split rate was $1 / 100$ and the injection volume was $1 \mu \mathrm{l}$. Hydrogen was used as the carrier gas and its flow rate was set at $1.5 \mathrm{ml} /$ minute.

The blood samples were allowed to coagulate for one hour and then centrifuged at $2260 \mathrm{xg}$ for five minutes. Extracted serum samples were stored at $-20^{\circ} \mathrm{C}$ until analysed. Total protein, albumin, glucose, aspartate aminotransferase (AST-SGOT), alanine aminotransferase (ALT-SGPT), cholesterol, high-density lipoprotein (HDL-cholesterol), low-density lipoprotein (LDL-cholesterol), and triglyceride levels in the blood serum were detected with a biochemical auto-analyser (Gesan, Italy) and commercial kits (Gesan Chem 200, Italy).

Data were analysed with SPSS 22 (SPSS Inc., Chicago, Illinios, USA). One-way analysis of variance was used to detect overall differences among the groups. Duncan's multiple comparison test was used to detect differences among the groups. The linear model for the analysis of variance was:

$$
Y_{i j k}=\mu+a_{i}+b_{j}+e_{i j k}
$$

where: $\mu=$ the population mean,

$a_{i}=$ the effect of the ith treatment group $(\mathrm{i}=1,2,3,4)$,

$b_{j}=$ the effect of the jth replicate $(\mathrm{j}=1,2,3,4,5)$, and

$e_{i j k}=$ the random residual error.

\section{Results and Discussion}

The major constituent of the basal diet was linoleic acid (49.46\%). Thus, the PUFA (53.87\%) and $n-6$ PUFA (49.46\%) contents of the diet were high. Because olive cake oil contains $8.43 \%$ olive oil, the major constituent of OCM was oleic acid (66.98\%), and thus the MUFA content of the OCM supplement was high (67.83\%). The fatty acid levels of the basal diet and OCM supplement are presented in Table 1. 
Table 1 Fatty acid composition of basal diet and olive cake meal supplement fed to Japanese quail

\begin{tabular}{lrc}
\hline Fatty acid, \% & Basal diet & Olive cake meal \\
\hline Myristic acid (C14:0) & 0.25 & 0.31 \\
Pentadecenoic acid (C15:1 cis-10) & 15.68 & 14.24 \\
Palmitic acid (C16:0) & 0.58 & 0.85 \\
Palmitoleic acid (C16:1) & 2.94 & 2.64 \\
Stearic acid (C18:0) & 25.87 & 66.98 \\
Oleic acid (C18:1) & 49.46 & 15.29 \\
Linoleic acid (C18:2n6) & 4.41 & 16.88 \\
a-Linolenic acid (C18:3n3) & 0.49 & 67.83 \\
Arachidic acid (C20:0) & 16.42 & 15.29 \\
\hline Saturated fatty acids (SFA) & 26.76 & 15.29 \\
Monounstaturated fatty acids & 53.87 & \\
Polyunsaturated fatty acids (PUFA) & 49.46 & 0.9 \\
n-6 PUFA & 4.41 & 8.43 \\
n-3 PUFA & 11.21 & 3.28 \\
Ratio of n6 PUFA to n3 PUFA & 5.39 & \\
PUFA/SFA & & \\
\hline Crude fat & & \\
\hline
\end{tabular}

No significant differences were detected between the treatments for serum total protein, serum mean albumin, AST-SGOT, ALT-SGPT, HDL-cholesterol, and triglyceride levels (Table 2). These results support results from some previous studies. Kara (2015) reported that no effect was observed on the serum total protein level in quail given 3\% of olive oil. Similarly, Sateri et al. (2017) reported that supplementation with olive meal had no effect on serum total protein and albumin levels in broiler chickens. Albumin, which is the protein that is found at the highest level in serum, serves as an important indicator of health status in poultry (Piotrowska et al., 2011). Alagawany et al. (2019) also described olive oil as a strong immunomodulator, which strengthens immunity. However, Saleh et al. (2020) reported that supplementation with OCM and probiotic (Bacillus licheniformis) increased serum total protein and albumin levels in broiler chickens. The reason for these levels not having increased in the present study could not be identified. Possibly, antioxidant and immunostimulatory substances in olives were lost in the production of OCM. Tiftik (1996) indicated that elevated serum AST-SGOT and ALT-SGPT levels could result from the disruption of cell membrane permeability or cell breakdown, and an increase in these levels was accepted as the most important indicator of internal organ damage. In the present study, no difference was detected for serum AST-SGOT and ALT-SGPT levels. This could be indicate that OCM consumption did not have a detrimental effect on the brain, liver, kidneys and other internal organs, and thus, the health of the quail was unharmed. The results of the present study agree with Kara (2015) in which supplementation of quail with $3 \%$ olive oil did not affect serum ALT and AST levels (Kara, 2015).

Supplementation with OCM affected the serum cholesterol and LDL-cholesterol levels. When compared with $\mathrm{C}$ and T2.5, the serum total cholesterol and LDL-cholesterol levels in T5 and T7.5 decreased $(P<0.05)$, whereas OCM had no effect on serum HDL cholesterol levels (Table 2). Although it is not known why T2.5 increased the total cholesterol and LDL cholesterol levels, a decrease in the same parameters in T5 and T7.5 was attributed to OCM having reduced the major SFA (C18:0 stearic) and increased the major MUFA (C18:1 oleic). Other reports suggested that because of their rich content of unsaturated fatty acids, olive by-products decrease total cholesterol and LDL cholesterol levels (El Hachemi et al., 2007; Al-Harthi, 2016). Similar to the present study, Saleh et al. (2020) determined that total HDL-cholesterol levels increased and total LDL-cholesterol levels decreased after supplementation with 4\% OCM in broiler chickens. These researchers also indicated that OCM supplementation did not alter serum triglyceride levels. On the other hand, Zhang et al. (2013) reported that the incorporation of $5 \%$ olive oil in the feed of broiler chickens decreased serum triglyceride and increased HDL-cholesterol levels. Al-Harthi (2016) found that supplementation with $5 \%$ and $10 \%$ olive cake increased triglyceride levels in broiler chickens. But other 
researchers reported that olive by-products had no effect on the constituents of serum (Kara, 2015; Bahşi et al., 2016; Sateri et al., 2017).

Table 2 Effects of level of olive cake meal included in the diet on serum protein and lipid constituents

\begin{tabular}{|c|c|c|c|c|c|c|}
\hline \multirow{2}{*}{ Serum constituents, mg/dl } & \multicolumn{4}{|c|}{ Level of olive cake meal in diet } & \multirow{2}{*}{ SE } & \multirow{2}{*}{$P$-value } \\
\hline & $0 \%$ & $2.5 \%$ & $5 \%$ & $7.5 \%$ & & \\
\hline Total protein & 3.50 & 3.80 & 3.25 & 3.45 & 0.118 & 0.358 \\
\hline Albumin & 1.29 & 1.37 & 1.41 & 1.26 & 0.067 & 0.851 \\
\hline Aspartate aminotransferase & 278.75 & 256.06 & 279.76 & 283.90 & 5.041 & 0.207 \\
\hline Alanine aminotransferase & 7.45 & 10.00 & 8.85 & 7.55 & 0.423 & 0.125 \\
\hline Total cholesterol & $216.45^{\mathrm{ab}}$ & $235.00^{\mathrm{a}}$ & $186.75^{c}$ & $193.50^{c}$ & 6.236 & 0.030 \\
\hline HDL cholesterol & 120.50 & 122.95 & 118.20 & 110.10 & 2.384 & 0.259 \\
\hline LDL cholesterol & $81.50^{\mathrm{ab}}$ & $111.30^{\mathrm{a}}$ & $64.15^{\mathrm{c}}$ & $74.60^{\mathrm{C}}$ & 6.158 & 0.050 \\
\hline Triglyceride & 574.90 & 650.50 & 496.80 & 655.65 & 6.942 & 0.770 \\
\hline
\end{tabular}

${ }^{a, b, c}$ Within a row, means with a common superscript were not different, with probability $P=0.05$

Dietary supplementation with OCM significantly affected breast meat cholesterol levels. The control group and the group that received 2.5\% OCM in the diet were similar to each other with 50.4 and $57.4 \mathrm{mg} / \mathrm{dl}$, respectively. As the amount of OCM in the diet was further increased to $5 \%$ and $7.5 \%$ the cholesterol level in the breast muscle also increased to 65.6 and $80.2 \mathrm{mg} / \mathrm{dl}$, respectively. This is contrary to T5 and T7.5 having reduced the serum total cholesterol and LDL cholesterol levels. Poultry meat, which is one of the most highly demanded types of meat, contains a lower level of cholesterol compared to red meat (Maiorano et al., 2009). To the authors' knowledge, there is no previous study on the investigation of the effect of OCM on breast meat cholesterol levels. However, the quail breast meat cholesterol levels reported by Maiorano et al. (2009) $(27.83-43.38 \mathrm{mg} / 100 \mathrm{~g})$ and Maiorano et al. $(2011)(23.57-37.20 \mathrm{mg} / 100 \mathrm{~g})$ were lower than the levels detected in the control group in the present study, and levels reported by Fakolade (2015) $(73.70 \mathrm{mg} / 100 \mathrm{~g})$, Devi et al. (2017) $(62.15 \mathrm{mg} / 100 \mathrm{~g})$, and Pavelková et al. (2020) $(79.0 \mathrm{mg} / 100 \mathrm{~g})$ are higher. Although the cholesterol levels in the present study in the groups that received OCM did not exceed the levels in control animals in previous studies (Fakolade, 2015; Devi et al., 2017; Pavelková et al., 2020), Because T5 and T7.5 increased breast meat cholesterol levels when compared with the control group, it is important to elucidate the underlying mechanism of this increase to ensure the production of healthy meat.

Dietary supplementation with OCM affected the levels of myristic acid (C14:0), palmitic acid (C16:0), palmitoleic acid (C16:1), stearic acid (C18:0), oleic acid (C18:1), $\alpha$-linolenic acid $C 18: 3(n 3)$, eicosatrienoic acid C20:3(n6), eicosatrienoic acid C20:3(n3), and nervonic acid (C24:1), and total SFA, MUFA, PUFA, n-3 PUFA rates, and the $n-6 / n-3$ ratio in the breast muscle of quail $(P<0.001)$ (Table 3$)$. The greatest alterations in breast muscle fatty acid composition were observed in T5. Of the major SFAs, palmitic acid (C16:0) had increased, whereas stearic acid $(\mathrm{C} 18: 0)$ had decreased $(P<0.001)$. The total SFA content had decreased $(P$ $<0.001)$. Of the major MUFAs, oleic acid $(\mathrm{C} 18: 1)$ and palmitoleic acid $(\mathrm{C} 16: 1)$ had increased in level $(P$ $<0.001)$. Thus, the MUFA content had increased $(P<0.001)$. Of the major polyunsaturated fatty acids (PUFA), eicosatrienoic acid (C20:3 (n3)) had decreased $(P<0.001)$. Thus, the PUFA content displayed a decrease $(P<0.001)$. Although OCM supplementation caused no significant alteration in the n-6 PUFA rate and PUFA/SFA ratio $(P>0.05)$, the nervonic acid (C24:1), PUFA and n-3 PUFA levels had decreased $(P$ $<0.001)$. In particular, T5 decreased the n-3 PUFA content $(P<0.05)$. Because of this decrease, the $n-6 / n-3$ ratio had increased in T5 $(P<0.001)$. When compared with $\mathrm{C}$, the breast meat oleic acid levels were observed to have increased almost twofold in T2.5 and threefold in T5, and to have decreased to a level close to that of T2 in T7.5. The basal diet contained a low percentage of oleic acid $(25.87 \%)$ and a high percentage of OCM (66.98\%), and the OCM supplement contained a high percentage of MUFA (67.83\%) (Table 3). Olive oil is rich in oleic acid, and thus in MUFA (Chiofalo et al., 2002; Badawy \& Saleh, 2018). Therefore, because the breast meat oleic acid levels of T2.5, T5, and T7.5 increased, this could be attributed to the composition of the OCM supplement (El Hachemi et al., 2007). On the other hand, in T7.5, the reason for breast meat oleic acid decreasing to levels close to those of T5 could not be explained. However, the higher unsaturated fatty acid content of T7.5 compared with T5 might have increased the rate of 
peroxidation, resulting in the partial oxidation of the unsaturated fatty acids. Papadomichelakis et al. (2019) reported that the percentage of olive pulp in feed should not exceed $5 \%$, otherwise the oxidative stability of meat would be harmed. Thus, it could be said that, oleic acid affects the fatty acid profile of the animal and increases the MUFA content of breast meat. The OCM in this study, which contained a high amount of MUFA (67.83\%), is an alternative and novel feedstuff that could be used safely to improve the lipid profile of poultry. This recommendation is based on the stearic acid, eicosatrienoic acid, SFA and PUFA levels being the lowest in the group with the highest MUFA level (T5). When compared with C, the low PUFA levels in the OCM groups could be related to the basal diet being maize and soybean based. Owing to the linoleic acid (C18:2(n6)) content of the feed being high (49.46\%) and the same content of the OCM supplement being low (15.29\%), the PUFA (53.87\%), and n-6 PUFA (49.46\%) percentages of the feed were high (Table 3$)$. Thus, the PUFA levels of $C$ were higher than those of the groups that received OCM. These results have demonstrated that the fatty acid profiles of animals vary with the composition of their feed and feed supplements, and that the targeted improvement is closely linked to the amount of fatty acids consumed.

Table 3 Effects of level of olive cake meal in diet on fatty acid composition of quail breast muscle

\begin{tabular}{|c|c|c|c|c|c|c|}
\hline \multirow{2}{*}{ Fatty acids, \% } & \multicolumn{4}{|c|}{ Level of olive cake meal in diet } & \multirow{2}{*}{ SE } & \multirow{2}{*}{$P$-value } \\
\hline & $0 \%$ & $2.5 \%$ & $5 \%$ & $7.5 \%$ & & \\
\hline Myristic acid (C14:0) & $0.096^{\mathrm{C}}$ & $0.178^{\mathrm{bc}}$ & $0.345^{\mathrm{a}}$ & $0.274^{\mathrm{ab}}$ & 0.021 & 0.001 \\
\hline Palmitic acid (C16:0) & $17.500^{b}$ & $18.712^{b}$ & $20.040^{\mathrm{a}}$ & $18.615^{\mathrm{b}}$ & 0.203 & 0.001 \\
\hline Palmitoleic acid (C16:1) & $0.435^{c}$ & $1.119^{c}$ & $3.462^{\mathrm{a}}$ & $2.066^{b}$ & 0.157 & 0.000 \\
\hline Heptadecanoic acid (C17:0) & 0.163 & 0.124 & 0.141 & 0.139 & 0.006 & 0.215 \\
\hline Stearic acid $(\mathrm{C} 18: 0)$ & $22.806^{a}$ & $19.115^{b}$ & $13.431^{\mathrm{c}}$ & $17.756^{\mathrm{b}}$ & 0.573 & 0.000 \\
\hline Oleic acid (C18:1) & $8.864^{c}$ & $14.942^{b}$ & $24.954^{\mathrm{a}}$ & $16.571^{b}$ & 0.818 & 0.000 \\
\hline Linoleic acid C18:2(n6) & 20.734 & 22.104 & 22.850 & 22.495 & 0.427 & 0.332 \\
\hline a-Linolenic acid C18:3(n3) & $0.263^{b}$ & $0.544^{\mathrm{ab}}$ & $0.869^{\mathrm{a}}$ & $0.693^{a}$ & 0.057 & 0.005 \\
\hline Arachidic acid (C20:0) & 0.088 & 0.104 & 0.076 & 0.092 & 0.009 & 0.743 \\
\hline Gadoleic acid C20:1 (n9) & 0.085 & 0.105 & 0.121 & 0.109 & 0.005 & 0.098 \\
\hline Eicosadienoic acid C20:2(n6) & 0.239 & 0.249 & 0.207 & 0.256 & 0.009 & 0.237 \\
\hline Eicosatrienoic acid C20:3(n6) & $0.445^{\mathrm{a}}$ & $0.384^{a}$ & $0.168^{b}$ & $0.352^{\mathrm{a}}$ & 0.018 & 0.000 \\
\hline Eicosatrienoic acid C20:3(n3) & $21.298^{\mathrm{a}}$ & $16.690^{\mathrm{b}}$ & $8.747^{\mathrm{C}}$ & $15.245^{\mathrm{b}}$ & 0.722 & 0.000 \\
\hline Lignoceric acid C24:0 & 0.924 & 0.975 & 0.688 & 1.069 & 0.057 & 0.131 \\
\hline Nervonic acid C24:1 & $3.590^{\mathrm{a}}$ & $2.782^{b}$ & $2.177^{\mathrm{b}}$ & $2.592^{b}$ & 0.108 & 0.000 \\
\hline $\mathrm{SFA}^{3}$ & $41.577^{\mathrm{a}}$ & $39.208^{\mathrm{ab}}$ & $34.721^{c}$ & $37.945^{\mathrm{b}}$ & 0.484 & 0.000 \\
\hline MUFA & $12.974^{\mathrm{c}}$ & $18.948^{\mathrm{b}}$ & $30.714^{\mathrm{a}}$ & $21.338^{\mathrm{b}}$ & 0.877 & 0.000 \\
\hline PUFA & $42.979^{a}$ & $39.971^{b}$ & $32.841^{c}$ & $39.041^{b}$ & 0.466 & 0.000 \\
\hline UFA (MUFA+PUFA) & $55.953^{c}$ & $58.919^{b c}$ & $63.555^{\mathrm{a}}$ & $60.379^{\mathrm{ab}}$ & 0.572 & 0.000 \\
\hline n-6 PUFA & 21.418 & 22.737 & 23.225 & 23.103 & 0.428 & 0.432 \\
\hline n-3 PUFA & $21.561^{a}$ & $17.234^{\mathrm{b}}$ & $9.616^{c}$ & $15.938^{b}$ & 0.677 & 0.000 \\
\hline n6/n3 ratio & $0.999^{c}$ & $1.501^{b c}$ & $2.483^{\mathrm{a}}$ & $1.791^{\mathrm{b}}$ & 0.102 & 0.000 \\
\hline PUFA/SFA ratio & 1.034 & 1.023 & 0.953 & 1.033 & 0.015 & 0.186 \\
\hline
\end{tabular}

${ }^{a, b, c}$ Within a row, means with a common superscript were not different with probability $P=0.05$

SFA: saturated fatty acids, MUFA: monounsaturated fatty acids, PUFA:polyunsaturated fatty acids

There are literature reports which agree with the results of the present study. Saleh et al. (2020) reported that supplementation with $4 \%$ of OCM increased oleic and linoleic acid levels in the breast meat of broiler chickens, up to $4 \%$ and $2 \%$, respectively. Upon determining that breast meat MUFA levels displayed significant dose-dependent increases in broiler chickens given olive pulp, Papadomichelakis et al. (2019) suggested that the MUFA content of meat could be improved by supplementation, but underlined that the 
percentage of olive pulp incorporated into feed should not exceed $5 \%$, as it would be detrimental to the oxidative stability of meat. Krejčí-Treu et al. (2010) ascertained that supplementation with olive oil increased oleic acid levels in the breast and thigh meat of broiler chickens, and affected their fatty acid profile. Zhang et al. (2013) reported that supplementation with $2 \%$ and $5 \%$ of olive oil decreased SFA levels, and increased UFA levels and the UFA/SFA ratio in the breast and thigh meat of broiler chickens, and pointed to olive oil as a beneficial fatty acid source for humans. Furthermore, Saleh et al. (2020) indicated that OCM improved the health status of animals by improving their plasma lipid levels and fatty acid profile. Upon incorporating $5 \%$, $10 \%$ and $15 \%$ of olive pulp into the mixed rations of broiler chickens, Tüzün and Ünlü (2016) observed a cubic increase in the PUFA level and a cubic decrease in the SFA and MUFA levels of thigh meat. Although differing from the present study in active substance composition, similar research on other olive by-products (olive leaf extract, oleuropein) demonstrated increased oleic acid, linoleic acid, n-6 fatty acid, and MUFA levels and n-6/n-3 fatty acid ratio, and decreased SFA levels in breast meat (Özdemir \& Azman, 2016; Bahşi et al., 2016; Ahmed et al., 2017). Furthermore, Sarıca \& Toptaş (2014) reported that while oleuropein had no effect on SFA, MUFA, PUFA, total $n-3$, and total $n-6$ levels or the $n-3 / n-6$ ratio in quail breast meat, oleuropein supplementation increased PUFA and omega-3 fatty acid levels in quail thigh meat.

\section{Conclusion}

Incorporation of OCM in quail feed reduced total cholesterol and LDL cholesterol, both of which are of major importance for human health. Dietary OCM did not affect AST and ALT levels, which are indicators of liver and brain damage. Therefore, OCM is considered not to harm animal health and to offer potential as a safe feed supplement. Compared with the other inclusion rates, T5 increased oleic acid (C18:1), linoleic acid (C18:3n3), and total MUFA and UFA levels to a greater degree, and decreased stearic acid (C18:0), total SFA and PUFA levels to a greater degree as well. Based on the parameters, it is suggested that OCM could be incorporated in poultry mixed rations as an alternative feedstuff at a level of $5 \%$. Because a comparative assessment could not be made of the increase in breast meat cholesterol levels from OCM supplementation, further investigation is needed to optimize such changes in this parameter.

\section{Authors' Contributions}

All authors contributed equally.

\section{Conflict of Interest Declaration} None.

\section{References}

Ahmed, M.M., El-Saadany, A.S., Shreif, E.Y. \& El-Barbary, A.M., 2017. Effect of dietary olive leaves extract (oleuropein) supplementation on productive, physiological and immunological parameters in Bandarah chickens 2- during production period. Egypt. Poult. Sci. 37(I), 277-292.

https://epsj.journals.ekb.eg/article_6783_80ac3f61788df1bcfe3add2889a504a9.pdf

Alagawany, M., Elnesr, S.S., Farag, M.R., Abd El-Hack, M.E., Khafaga, A.F., Taha, A.E., Tiwari, R., Yatoo, M.I., Bhatt, P., Khurana, S.K. \& Dhama, K., 2019. Omega-3 and omega-6 fatty acids in poultry nutrition: Effect on production performance and health. Animals 9(8), 573. https://www.ncbi.nlm.nih.gov/pmc/articles/PMC6721126/pdf/animals09-00573.pdf

Al-Harthi, M.A., 2016. The efficacy of using olive cake as a by-product in broiler feeding with or without yeast. Ital. J. Anim. Sci. 15(3), 512-520. https://doi.org/10.1080/1828051X.2016.1194173

Anonymous, 2020. Olive cake - Morova. (In Turkish) https://morova.com/services/zeytin-kuspesi/

Anonymous, 1996. Hayvansal ve bitkisel katı ve sıvı yağlar- Yağ asitleri metil esterlerinin gaz kromatoğrafisiyle analizi. TSE yayınları, TS No: TS 4664 EN ISO 5508, Ankara.

Badawy, W.Z. \& Saleh, A.A., 2018. Utilization of olive cake by-product for improvement of shelf life and quality of chicken meat. Zagazig J. Agric. Res. 45(5), 1701-1709. https://journals.ekb.eg/article_48437.html

Bahşi, M., Çiftci, M., Simsek, Ü.G., Azman, M.A., Özdemir, G., Yilmaz, Ö. \& Dalkilic, B., 2016. Effects of olive leaf extract (oleuropein) on performance, fatty acid levels of breast muscle and some blood parameters in Japanese quail (Coturnix coturnix Japonica) reared in different stocking densities. Vet. J. of Ankara Univ. 63, 61-68. http://vetjournal.ankara.edu.tr/tr/download/article-file/657231

Cayan, H. \& Erener, G., 2015. Effect of olive leaf (olea europaea) powder on laying hens performance, egg quality and egg yolk cholesterol levels. Asian Australas. J. Anim. Sci. 28(4), 538-543. http://dx.doi.org/10.5713/ajas.14.0369

Chiofalo, B., Liotta, L., Zumbo, A. \& Chiofalo, V., 2002. Olive cake for ewe feeding: effect on the milk acidic composition. In: Proceedings of the 15th National Congress of SIPAOC, Cagliari, Italy, pp. 136-137.

De Almeida, J.C., Perassolo, M.S., Camargo, J.L., Bragagnolo, N. \& Gross, J.L., 2006. Fatty acid composition and cholesterol content of beef and chicken meat in Southern Brazil. Braz. J. Pharm. Sci. 42, 109-117. https://www.scielo.br/scielo.php?script=sci_arttext\&pid=S1516-93322006000100012\&lng=en\&nrm=iso

Devi, T.N., Ramani, R., Babu, R.N., Rao, V.A., Ramesh, J. \& Abraham R.J.J., 2017. Effect of cooking on cholesterol and proximate composition on breast and thigh muscles of chicken and quail meat. Int. J. Curr. Microbiol. App. Sci. 6(10), 3700-4703. https://www.ijcmas.com/6-10-2017/T.\%20Nandini\%20Devi,\%20et\%20al.pdf 
El Hachemi, A., El Mecherfi, K.E., Benzineb, K., Saidi, D. \& Kheroua, O., 2007. Supplementation of olive mill wastes in broiler chicken feeding. Afr. J. Biotechnol. 6(15), 1848-1853. https://www.researchgate.net/publication/27797875

Fakolade, P.O., 2015. Effect of age on physico-chemical, cholesterol and proximate composition of chicken and quail meat. AJFS 9(4), 182-186. https://www.researchgate.net/publication/286775195

Folch, J., Lees, M. \& Sloane-Stanley, G.H., 1957. A simple method for the isolation and purification of total lipids from animal tissues. JBC 226(1), 497-509. https://pubmed.ncbi.nlm.nih.gov/13428781/

Gonçalves-de-Albuquerque, C.F., Medeiros-de-Moraes, I.M., Oliveira, F.M. de J., Burth, P., Bozza P.T., Faria M.V.C., Silva A.R. \& Caire de Castro-Faria-Neto H., 2016. Omega-9 oleic acid induces fatty acid oxidation and decreases organ dysfunction and mortality in experimental sepsis. Plos One 11(4), e03607 https://www.researchgate.net/publication/301299549

Kara, Z., 2015. Effects of different oil sources supplementation in quail diets on fattening performance, carcass traits, some blood parameters and oxidative status. Master's thesis, Afyon Kocatepe University Institute of Health Sciences. P. 54.

Krejčí-Treu, T., Straková, E., Suchý, P. \& Herzig, I., 2010. Effect of vegetable oil fortified feeds on the content of fatty acids in breast and thigh muscles in broiler chickens. Acta Vet. Brno 79, 21-28. https://doi.org/10.2754/avb201079S9S021

Maiorano, G., Elminowska-Wenda, G., Mika, A., Rutkowski, A. \& Bednarczyk, M., 2009. Effects of selection for yolk cholesterol on growth and meat quality in Japanese quail (Coturnix coturnix japonica). Ital. J. Anim. Sci. 8, 457466. https://www.tandfonline.com/doi/abs/10.4081/ijas.2009.457

Maiorano, G., Knaga, S., Witkowski, A., Cianciullo, D. \& Bednarczyk M., 2011. Cholesterol content and intramuscular collagen properties of Pectoralis superficialis muscle of quail from different genetic groups. Poult. Sci. 90(7), 1620-1626. https://pubmed.ncbi.nlm.nih.gov/21673181/

Medeiros-de-Moraes, I.M., Gonçalves-de-Albuquerque, C.F., Kurz, A.R.M., Oliveira, F.M. de J., Abreu, V.H.P., Torres, R.C., Carvalho, V.F., Estato, V., Bozza,P.T., Sperandio, M., Castro-Faria-Neto, H.C. \& Silva, A.R., 2018. Omega9 oleic acid, the main compound of olive oil, mitigates inflammation during experimental sepsis. Hindawi Oxidative Medicine and Cellular Longevity 1-13. https://doi.org/10.1155/2018/6053492 .

$\mathrm{NRC}, 1994$. Nutrient requirements of poultry. 9th edition. National Academy Press. Washington DC, USA.

Özdemir, A. \& Azman, M.A., 2016. Effects of olive leaf extract and vitamin E supplementation in quail diet on some blood parameters and egg yolk fatty acids composition. Vet. J. Ankara Univ. 63, 31-37. http://vetjournal.ankara.edu.tr/tr/download/article-file/657216

Papadomichelakis, G., Pappas, A.C., Tsiplakou, E., Symeon, G.K., Sotirakoglou, K., Mpekelis, V., Fegeros, K. \& Zervas, G., 2019. Effects of dietary dried olive pulp inclusion on growth performance and meat quality of broiler chickens. Lvstck. Sci. 221, 115-122. https://doi.org/10.1016/j.livsci.2019.01.023

Pavelková, A., Haščík, P., Kalafová, A., Capcarová, M., Čuboň, J., Bučko, O., Kačániová, M., Hanusová, E., Tkáčová, J. \& Bobko M., 2020. Chemical composition of muscle after bee bread application in the nutrition of Japanese quail. J. of Microbiol. Biotech. Food Sci. 9(4), 831-835. https://www.pablikado.cz/dokument/JMFgcqMFu1cVqqft

Perdomo, L., Beneit, N., Otero, Y.F., Escribano, Ó., Sabela Díaz-Castroverde, S.D., Hernández, A.G. \& Benito, M., 2015. Protective role of oleic acid against cardiovascular insulin resistance and in the early and late cellular $\begin{array}{lllll}\text { atherosclerotic } & \text { process. } & \text { Cardiovascular } & \text { Diabetology } & 14,\end{array}$ https://www.ncbi.nlm.nih.gov/pmc/articles/PMC4475625/

Piotrowska, A., Burlikowska, K. \& Szymeczko, R., 2011. Changes in blood chemistry in broiler chickens during the fattening period. Folia Biol. (Krakow) 59(3-4),183-187. DOI: 10.3409/fb59_3-4.183-187

Saleh, A.A., Ahamad Paray, B. \& Dawood, M.A.O., 2020. Olive cake meal and Bacillus licheniformis impacted the growth performance, muscle fatty acid content, and health status of broiler chickens. Animals 10(4), 695. https://www.ncbi.nlm.nih.gov/pmc/articles/PMC7222747/

Sarica, S. \& Toptas, S., 2014. Effects of dietary oleuropein supplementation on growth performance, serum lipid concentrations and lipid oxidation of Japanese quails. J. Anim. Phys. Anim. Nutr. 98(6),1176-1186. https://onlinelibrary.wiley.com/doi/abs/10.1111/jpn.12192

Sateri, S., Seidavi, A., Bouyeh, M., Neumann, P., Kutzler, M., Laudadio, V., Loperfido, F. \& Tufarelli, V., 2017. Effect of olive meal and supplemental enzymes on performance traits, blood biochemistry, humoral immunity response and caecal microbiota of broilers. S. Afr. J. Anim. Sci. 47(6), 804-812. https://dx.doi.org/10.4314/sajas.v47i6.8

Stark, A. H. \& Madar, Z., 2002. Olive oil as a functional food: epidemiology and nutritional approaches. Nutr. Rev. 60(6), 170-176. https://doi.org/10.1301/002966402320243250

Tiftik, A.M., 1996. Klinik Biyokimya. Mimoza Yayınları, Konya, ss: 1-413.

Tüzün, A.E. \& Ünlü, H.B., 2016. Performance and fatty acids composition of thigh meat of broilers fed with diets supplemented olive pulp at different levels. J. Anim. Prod. 57(2), 15-21. https://dergipark.org.tr/en/download/article-file/327801

Zhang, Z.F., Zhou, T.X. \& Kim, I.H., 2013. Effects of dietary olive oil on growth performance, carcass parameters, serum characteristics, and fatty acid composition of breast and drumstick meat in broilers. Asian-Aust. J. Anim. Sci. 26(3), 416-422. https://www.ajas.info/journal/view.php?doi=10.5713/ajas.2012.12486 